\title{
Geophysical investigations in the Flumendosa River Delta, Sardinia (Italy) — Seismic reflection imaging
}

\author{
Gian Piero Deidda ${ }^{1}$, Gaetano Ranieri ${ }^{1}$, Gabriele Uras ${ }^{1}$, Pietro Cosentino ${ }^{2}$, and \\ Raffaele Martorana ${ }^{2}$
}

\begin{abstract}
A geophysical investigation that included seismic-reflection surveying and time-domain electromagnetics(EM) was carried out in the Flumendosa River Delta plain in southeastern Sardinia, Italy. The objective was to improve knowledge of geologic and hydrogeologic controls on a highly productiveaquife $r$ hostedin thick Quaternarydeposi ts andknown to be affected by an extensive saltwater intrusion. The seismic reflection survey, whose results are reported here, aimed to image the Paleozoic bedrock topography and to obtain detailed structural and stratigraphic information on the sequence of largely fluvial sediments extending from the surfacedown to bedrock. The surveyconsis tedof twoinlineprofiles, nearly parallel to the coastline and $1 \mathrm{~km}$ inland. The sources $(0.25 \mathrm{~kg}$ of explosives buried at $2 \mathrm{~m}$ depth $)$ and receivers (50-Hz vertical geophones) produced a twelvefold data set with common midpoints every $2.5 \mathrm{~m}$. Detailed integrated velocity analysis (constant velocity gathers, constant velocity stacks, and semblance plots ) and frequency-wavenumber-domain dip moveout (DMO) proved to be the most important processing steps in producing the two stacked sec-

\section{tions Both sections were characterized by distinct seismic
units boundedby quasi-continuous reflectors. The lowermost} reflection, imaged on section 1 at two-way traveltimes between $310 \mathrm{~ms}(\sim 300 \mathrm{~m})$ and $580 \mathrm{~ms}(\sim 530 \mathrm{~m})$ and on section 2 between $200 \mathrm{~ms}(\sim 190 \mathrm{~m})$ and $65 \mathrm{~ms}(\sim 52 \mathrm{~m})$, was interpreted to be Paleozoic bedrock.A maximum depth twice as deep as expected was the primary and somewhat surpris ingresult . Imaging of obliqueprogra dational facies - another major finding — proved the existence of undocumented marine Pleistoc ene sediments that could help in revising the area's geology.
\end{abstract}

\section{INTRODUCTION}

Witha rapidlyincreasing population density, particularly in coastal areas, the quantityand quality of water have become rate-limiting parameters in land management. Proper water-resource management relies on the development of accurate, predictive groundwaterflow models. However, the accuracy of the models is largely dependent upon our ability to determine adequately the geometries of geologic structures and hydrogeologic systems. Groundwater-flow models usually are developed from information obtainedby drilling observation wells. However, when geologic settings are complex and/or aquifers are deep, surface geophysical surveys can provide a more economical approach withsuffic ientdetailfor modeling.

Amongthe variousgeophysical methods, seismic reflection, electric, and EM techniques appear to be the most suitable for this purpose. Seismic reflection profiling potentiallycan providean accurate spatial representation of geologic, structural, and stratigraphic boundaries (Birkelo et al., 1987; Jongerius and Helbig, 1988; Geissler, 1989; Miller et al., 1989; Miller and Steeples, 1990; Liberty, 1998; Whiteleyet al., 1998). However, electricand EM methods are better suited for identifying hydrogeologic units(Fitterman and Stewart, 1986; Poulsen and Christensen, 1999) and distinguishing between freshwater and saltwater(Mills et al.,1988; Goldman et al., 1991).

Following thegeneralappro ach reported in Shtivelmanand Goldman (2000), a geophysicalsurveyusingseismi c-reflection andtimedomainelectromagnetic (TDEM) methods wasconduc ted to study a complex coastal aquifer of vital importance in the southeastern part of Sardinia, Italy. This insufficiently explored study area is the delta plain of the Flumendosa River, which hosts a highly productive aquifer. Unfortunately, the aquifer has been affected by extensive saltwater intrusion caused mainly by uncontrolled overexploitation of groundwaterresou rces fordrinki ng water andirrigat ionpurpos es, by fishfarmi ng, and by a decrease in naturalrechar ge of coastalaquifers as a result of upstream damming. Detailed knowledge of the ar-

Manuscript received by the Editor February26, 2005; revised manuscript received June24, 2005; publishedonlineAugu st 7, 2006.

${ }^{1}$ University of Cagliari, Dipartimento di Ingegneria del Territorio, Sezione di GeologiaApplicata e Geofisica Applicata, Piazza d'Armi, 16, Cagliari 09123, Italy.E-mail:gpdeidda@unica.it; granieri@unica.it; urasg@unica.it.

${ }^{2}$ University of Palermo, Dipartimento di Chimica e Fisica Della Terra edApplicazioni Alle Georisorse e ai Rischi Naturali, ViaArchirafi 26, Palermo 90123,

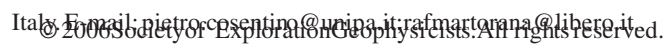


ea's geology and hydrogeology is vitally important because prolonged periods of drought have made groundwater the region's predominant (ifnot sole) water resource.

Generally, quantitative interpretation of subsurface geology requires borehole information. However, because such information is unavailable in the present case, we must rely chiefly on geophysical data for determining the geometry of subsurface structures, with the result that certain aspects remain speculative. Nevertheless, highqualitygeophy sical imaging can providedetaile d, useful subsurface information that cannot be obtained through sparsely spaced drill-
holes.

Here, we report the results of a 2D seismic reflection survey designed to image the Paleozoic bedrock topography and to obtain structural and stratigraphic information on the sequence of largely fluvial sediments extending from the surface down to the bedrock boundary. Since we could obtain no certain a priori information about bedrockdepth forthis location, we assumed a maximum depth of 200-300 m (Di Gregorio, personal communication, 2002), based only on surface geologic and geomorphologic information and bedrock depths from similar areas in Sardinia. The high-quality seismic sections reveal a complex bedrock topography with unexpected maximum depths of about $530 \mathrm{~m}$. The results also show interesting stratigraphic features characteristic of fluvial deltaic environments that could be of great importance for future groundwater exploitation.

\section{SURVEY LOCATION AND GEOLOGIC SETTING}

The coastal plain of the Flumendosa River on the southeastern coast of Sardinia (Figure 1) extends from the Tyrrhenian Sea to the villageof SanVito(S. Vito), $7 \mathrm{~km}$ westward. Prior to thisproje ct,little detailed information was available on its geology, despite more than 2000 exploitation wellsdril ledin thearea. In fact,noneof these wells, which extend no more than $50 \mathrm{~m}$ in depth, sampled the bedrock (Paleozoic) section.
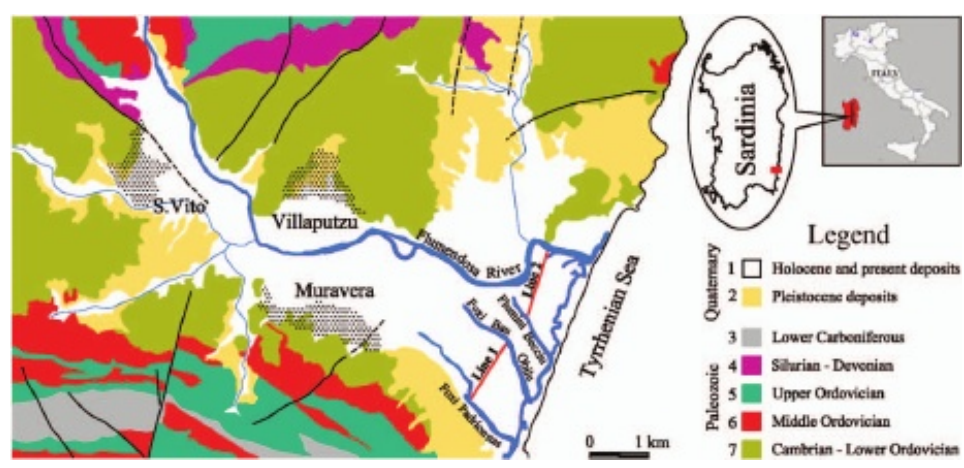

Figure 1. Map showingloca tion of seismic lines and a simplified geology forthe Muravera plain survey area. Unit 1: Alluvial (second-order alluvial terraces), colluvial, eolian, and littoral gravels, sand, silt, and clays. Unit 2: Conglomerates and sands forming a system of alluvial terraces (first order) linking up with the Piedmont alluvial fan of detritic material. Units 3-6: Metamorphic rocks (mainly metaconglomerates, metasandstones, metasiltstones, metalimestones, and porphyritic metavolcanic rock that represent the Paleozoic basement. Unit 7: The Arenarie di S.Vito Formation (irregular sequences of micaceous metasandstones and metaquartzarenites is the most important outcropping
unit bordering the Muravera plain.
The map in Figure 1 is based on surface outcrops of Paleozoic rocks and general geologic features in the area. Schematically, the geology of the area is characterized by a Paleozoic metamorphic basement overlain by a thick Quaternary alluvial blanket. The basement, whichoutc rops at theedge s of the plain, consists of the Paleozoic Arenarie di S. Vito Formation(Cambrian-Ordovician), a thick $(>500 \mathrm{~m})$ terrigenous succession of irregular sequences of mica-

metasandstone and metartzarenite.

Both Pleistocene and Holocene sediments can be recognized in the Quaternary alluvial deposits. Surface geology and geomorphology, together with bedrock depth information from similar areas, tocene sediments are mostly fluvial continental facies, with local marine facies (Tyrrhenian transgression) located slightly south of the area of investigation (Barca et al., 1981). These sediments are comprised of tabular beds of coarse conglomerates with a leansandshale matrix thataltern ateswith thin bedsof redsiltst one.Thesesediments, which were probably reincised during the peak of the Würmian marine regression, form a system of alluvial terraces(first order) that outcrop fairly continuously along the banks of the Fluendosa River and its tributaries and linkup with Piedmont alluvia etritic material. Holocene alluvialmateria 1, largelydeposi ted during the weak Versilian transgression, is comprised of coarse conglomerates witha shaly sandmatrixprevai lingover pebbles. Afterward, this formation was reincised, forming a system of second order alluvial terrac es that extends throughout much of the plain. A few meters of present alluvial sediments(gravel and sand) complete the Quaternary sequenc e. Although there are no certain indications of pre-Tyrrhenian marine transgression(Eocene?), the presence of alluvialdepo sits of that ageat the base of the Quaternary sedimentation, 2002)

Paleozoic formations in the area are characterized by low-grade metamorphism and two phases of Hercynian tecto nics. A system of isoclinal folds with axes striking east-west appears to be related to the first phase, whilethe foldsrela tedto theseco nd phase show axes with a northwest-southeast trend. The main regional fractures (Carmignani et al., 2001 ) striking east-west and northwest-southeast are normal. Strike-slip faults have resulted in the Cambrian units overlapping the Silurian-Devonian and Carboniferous units (Barca and Maxia, 1982).

A north-south-striking fault system, well
known both on dry land and in the continental shelf of southeast Sardinia, is the most important feature of post-Hercynian tectonics. This fault system, associated with Alpine tectonics, has offset the eastern side of the area by about 200 $300 \mathrm{~m}$ (Calvino, 1961). In particular, these faults, which cut through the Eocene deposits (sandstone and conglomerates ) a little farther to the northwest of thesurvey ed area(Carmignaniet al., 2001), could have offset the Eocene deposits themselves in the eastern part, protecting them from complete erosion (Di Gregorio, personal communication, 2002). North-south-striking normal faults, dated to the upper Miocene-Pleistocene, also have been imaged during earlier deep seismic surveys acquired offshore opposite the Muravera plain (Fabrettiet al., 1995). 


\section{DATA ACQUISITION}

The seismic reflection survey includes two P-wave seismic lines, bothappro ximately $1.1 \mathrm{~km}$ long (lines 1 and 2 in Figure 1 ). A few meters above sealeve 1 in the plain, thetopo graphy is flat with a maximum elevation variation of only about $0.5 \mathrm{~m}$. Logistical impediments, such as fish farming systems, buildings, and rice fields, prevent the acquisition of a single longline.

For both lines, seismic data were acquired using single $50-\mathrm{Hz}$ geophones attached to a 48 channel seismogr aph system with 18-bit recording capability. The sample interval was $0.5 \mathrm{~ms}$ andthe record length $1024 \mathrm{~ms}$ (Table 1).

In general, for seismographs that record at 16 bitsor more, itis best toreco rdusin g only a preanalog-to-digital (A/D) antialiasing filter (Steeples et al., 1997). In areaswith significantlevelsof ambient noise or characterized by highamplitude surface waves, additional low-cut frequency filtering prior toA/D conversionmightbe advisable.In thepresen t case, a $50-\mathrm{Hz}$ low-cut filter (24-dB/octave roll off) helped to attenuate ground roll better.

Data were recorded using a standard common-midpoint (CMP) roll-along technique in an end-on configuration with 48 active geophones. A $0.25-\mathrm{kg}$ explosive source was buried at approximately

$2 \mathrm{~m}$ depth (generally below the water table) for each shot position. Geophone spacing of $5 \mathrm{~m}$ and source spacing of $10 \mathrm{~m}$ provided twelvefold CMP coverage with a CMPspacing of $2.5 \mathrm{~m}$. The maximumsource -receiver offset of $245 \mathrm{~m}$ was chosen to allow the determination of stacking velocities for reflections from depths of about 200-300 m (e.g., from theexpecte d bedrocksurfa cd).

\section{DATA ANALYSIS, PROCESSING, AND RESULTS}

Thedata were generally of highqualit y, so they required relatively simple processing using commercial software (Table 2). Because noise and signal varied along the lines, shot-record-oriented processingwas effective forimprov ingS/ $\mathrm{N}$ ratio and introduced few computation-related artifacts intothe data.

Figure 2 shows shot gathers recorded at three locations along line 1 . Reflections are evident above $600 \mathrm{~ms}$. In record 13 , the reflection at around $400 \mathrm{~ms}$ (event $a$ ) shows distorted hyperbolic moveout, suggesting a dip-moveout(DMO) effect caused by a downdip reflector. The upper part of record 29 shows clear first breaks followed by reverberating arrivals(event $b$ ). Finally, record 53 is characterized by low-frequency, high-amplitude ground roll (event $c$ ). However, note the clear reflection at about $550 \mathrm{~ms}$ (event $d$ ), where reversed moveout suggests an updip reflector at thislocati on

Figure 3 displays three representative shot gathersrecor dedalong line 2 . TheS/N ratio foral
records along line 2 is less than that for line 1. A
Table 1. Seismic data acquisition equipment and parameters.
Energy source

Shotspacing

Minimumoffset

Time sampling interval

Analog low-cut filter 48-channel Abem Mark 6 seismograph

Blasting cap plus $0.25-\mathrm{kg}$ booster

$50 \mathrm{~Hz}$ (vertical)

$5 \mathrm{~m}$

$10 \mathrm{~m}$

Offend

$10 \mathrm{~m}$

$1024 \mathrm{~ms}$

$0.5 \mathrm{~ms}$

$50 \mathrm{~Hz}, 24 \mathrm{~dB} /$ octave
Table 2. Seismic data processing sequence.

Data conversion

Geometry

Editing

First-break muting

Spectral analysis and frequency filtering

Predictive deconvolution

Scaling

Velocity analysis

DMO correction

NMO correction

Residual statics

Stack

$f-k$ migration

Time-to-depth conversion

\section{Source-to-receiver offset $(\mathrm{m})$}

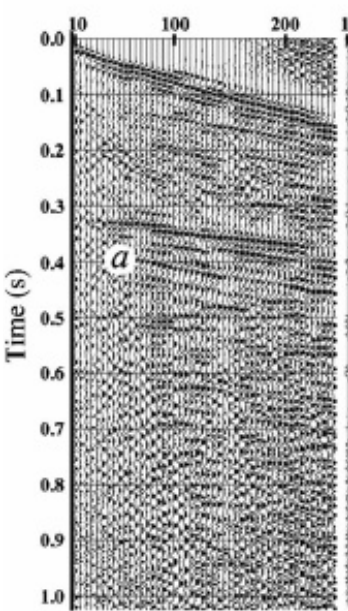

Rec. 13

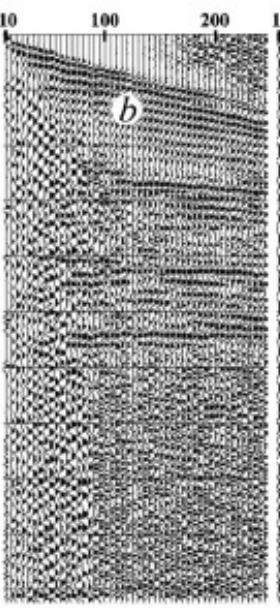

Rec. 29

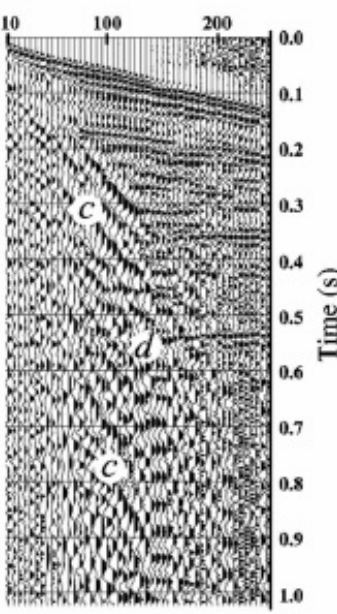

Rec. 53
Figure 2. Raw field files from threeloca tions along seismic line 1(locations indicated by arrows in Figure 5a). For display purposes, automatic gain control(AGC) scaling with a 100-ms window has been applied. Letters $a, b, c$, and $d$ highlight events described in the
text. 
strong airwave (event $e$ ) is evident in all records. Event $f$, with clear reversed moveoutfrom record 3 visibleup to record 11 , suggests the presence of an updip reflector at the beginning of the line, whereas record 72 on the right, representa tive of records at the end of line 2, shows clearly refracted arrivals $g$, indicating the presence of a refractorat shallower depths.
Initial processing steps involved setting up the geometry, followed by routine editing of the entire data set. To avoid misprocessing refractions as reflections, a hand-picked early mute was applied. The reverberations present in some records(such as those observed in record 29 of line 1 ) were attenuated by predictive-deconvolution filtering. Butterworth filtering $(50-180 \mathrm{~Hz}, 24 \mathrm{~dB} /$ octave $)$ helped attenuate ground roll. Surgical muting was used to remove the airwave fromrecor ds from line2.

As is often the case, detailed velocity analysis proved to be the most important and time-consuming processing step. For both lines 1 and 2, the initial velocity models were developed through integrated analysis of constant velocity gathers, constant velocity stacks, and semblance plots. Hand-picked direct arrivals supplied additional information on near-surface velocities. Refracted arrivals, clearly visible in the last records oflin e 2 (e.g., record 72 on Figure 3), allowed apparent velocityto be measured(4200-7000 m/s ) in theupper partof the Paleozoic basement.

As shown by clear reflections in Figure $4 \mathrm{a}$ and the relativelysharp peaks in thesembla nceplot of Figure 4b, resolution of stacking velocities was quite good for events above $500 \mathrm{~ms}$ traveltime, while velocity resolution was poor between 500 and $600 \mathrm{~ms}$. Prestack process ing was completed withthe applicationof static corrections. Because topography was flat, only residual static corrections were calculated and applied. Five iterations of surface-consistent statics with a maximum allowable shift of $\pm 5 \mathrm{~ms}$ improved the continuity of some events.

To obtain the final stacked-time sections from line 1 (Figure 5a) and line 2 (Figure 6a), further processing was required. Preliminary stacks confirmed the presence of dipping reflect ors, as shown in Figure 7 (relative to line 1). To moveout-correct these records properly, dip moveout (DMO) was applied in the $f-k$ domain. Figure $7 \mathrm{~b}$ shows the improvement from DMO and an improved stacking velocityfield. Optimum stacking velocities along lines 1 and 2 are shown in Fig-

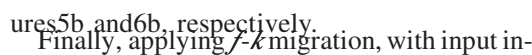
terval velocities obtained by converting stacking velocities in Figures $5 \mathrm{~b}$ and $6 \mathrm{~b}$ using Dix equations (Dix, 1955), both DMO-corrected sections were time migrated to obtain the sections in Figures $5 \mathrm{c}$ and $6 \mathrm{c}$. Migration was successful where full coverage and detailed velocity models were available. The primary reflecting horizons are clear and can be correlated quite easily with those on the unmigratedtime sections.

In general, with a detailed velocity model, migration improves interpretation because the depths of the reflectors can be determined more accurately, scattering is reduced, and dipping reflectors are positioned better. However, the smearing effect of the migration operator could obscure some details and produce artificial align-
Figure4. (a) CMPsuper gather derivedfrom three adjacentCMP gathersalong line 1 near the location marked with a blackstarin Figure 5a.(b) Corresponding semblance analysis showing the estimated velocity function. (c) Interval velocities determined by the Dix equation. Stacking yelocities were based on an integrated evaluation of constant velocity
gathers, constant velocitystacks, and semblance analysis. 
a) s-sw

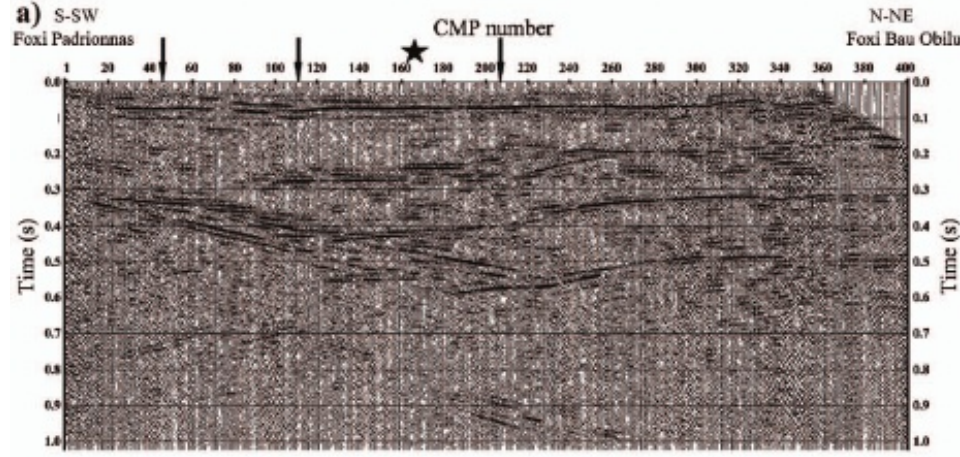

b)

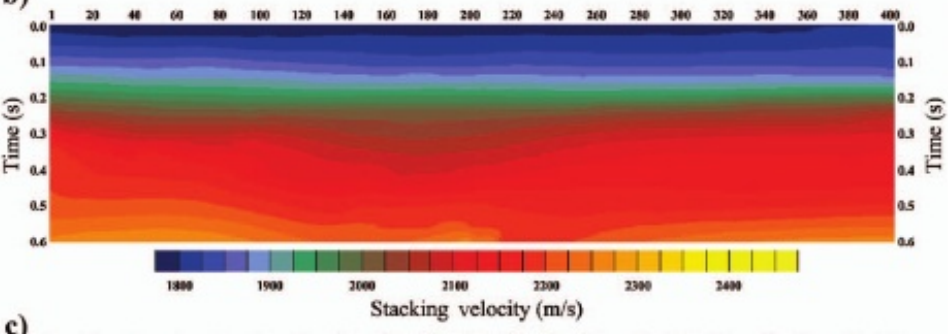

c)

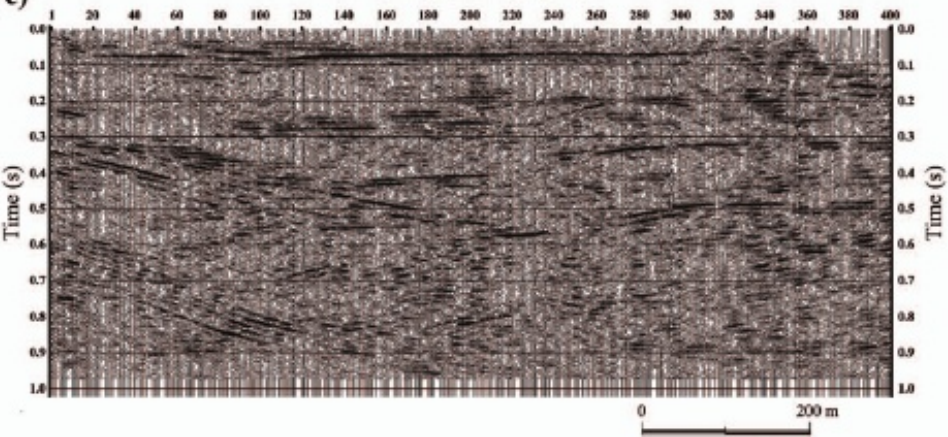

Figure5. (a) Time sectionalong line1 (shown inFigu re1).Arrow s mark shot positions of rawfield files in Figure 2. Black starindica testhe position of theCMP supergather in Figure 4. (b) Optimum stacking velocities after dip moveout.(c) An $f-k$ migrated time section obtainedfrom timesectio $n$ in Figure 5a,using an intervalveloci ty fieldderive $\mathrm{d}$ from

stacking velocities in Figure $5 b$.

ments. Further problems arise in the present case because the reflectors are too close to the section ends and because, for line 1 , the velocities of the deepest reflectors are poorly determined. For these reasons, we based ourinterpr etation on the unmigrated time sections combined with the depth-convertedmigrated sections.

\section{INTERPRETATION}

The preferred interpretations of seismic sections from lines 1 and 2 are displayed in Figures 8 and 9, respectively. For a clearer understanding, the description and interpretation of the sections are dis-

cussedseparately becausethe sections themselves differ substantial-
ly. Since ho velocityinfor mation fromboreh oleswas available in the investigated area, depth conversion(Figures $8 b$ and 9b) was done based on seismic velocities. Depth sectionsare relativeto sea level, which lies about $2.5 \mathrm{~m}$ below the surface.

\section{Reflection line 1}

Line 1 begins east of the Paleozoic outcrop at the Foxi Padrionnas bank (Figure 1) and terminates on the right bank of the Foxi Obilu, following a direction parallel to the coastline $1 \mathrm{~km}$ inland. The detailed unmigrated seismic section reveals a complex stratigraphic and structural subsurface framework along the survey line(Figure $8)$. The dominant feature is a reflection visible throughout the entire section, with an apparent dipto the north-northeast, from310-580 mstwoway traveltime (twtt) between CMP locations 1 and185 (event $\alpha$ ).At CMP locations 133 and 185 (530and $580 \mathrm{~ms}$ twtt, respectively), event $\alpha$ hasa bowtie feature (crossing reflections), then dips south-southwest from 580-540 ms twtt with another bowtie featu re at CMP location 230. Fin ally, event $\alpha$ shallows tothe end of the line, wher e it appears nearly horizontal. The bowtie features, together with the general geometry of event $\alpha$, suggest fault zones may be present around locations 133,185 , and 230. We interpret event $\alpha$, the deepest coherentreflect ion, as the top of the Paleozoic basement, whereasthe faults marked on the interpreted section might be Hercynian direct faults, striking east-west or northwest-southeast, that fit the regional tectonics and are well documented in the region surrounding the survey area (Carmignani et al.,2001).

Another strong reflection (event $\beta$ ) dominates the right part of the section. It starts from $430 \mathrm{~ms}$ twtt, pinches out between locations 125 and 130 , and thensha llows to310 mstwt t atthe end ofthe line, similar to event $\alpha$. The seismic unit $\mathrm{C}$ between events $\alpha$ and $\beta$ isthe most difficult to interpret. Because of unit C's great depth $\quad(>300$

m) and thickness, itis unlikely to be Pleistocene havethickunits of thistype of sediment beendocumented). Thus, this unit is more likely to be part of the Eocene deposits cropping out around $10 \mathrm{~km}$ northwest of the surveyed area (Carmignani et al., 2001 ) — deposits lowered eastward by a north-south fault system during the Alpine orogeny. During the Eocene, a vast area in southeast Sardinia, including the surveyed area, was submerged in the sea. Although most of the sediments deposited during this period have been eroded, complete erosion in the study area could have been prevented by Alpine tectonic dislocations (Calvino, 1961). This interpretation suggests that the strong reflection (event $\beta$ ) at the top of unit $\mathrm{C}$ might be an erosion surface thatforme $\mathrm{d}$ during the post-Eocenemarin e regression.

The other well-defined event(event $\gamma$ ) in this section is the shallowestreflecti on with onset at about $68 \mathrm{~ms}$ twtt. Event $\gamma$ appearsas a flat event throughout the entire section, and its positionagrees with
the boundary between recent (Holocene) and ancient (Pleistocene) 

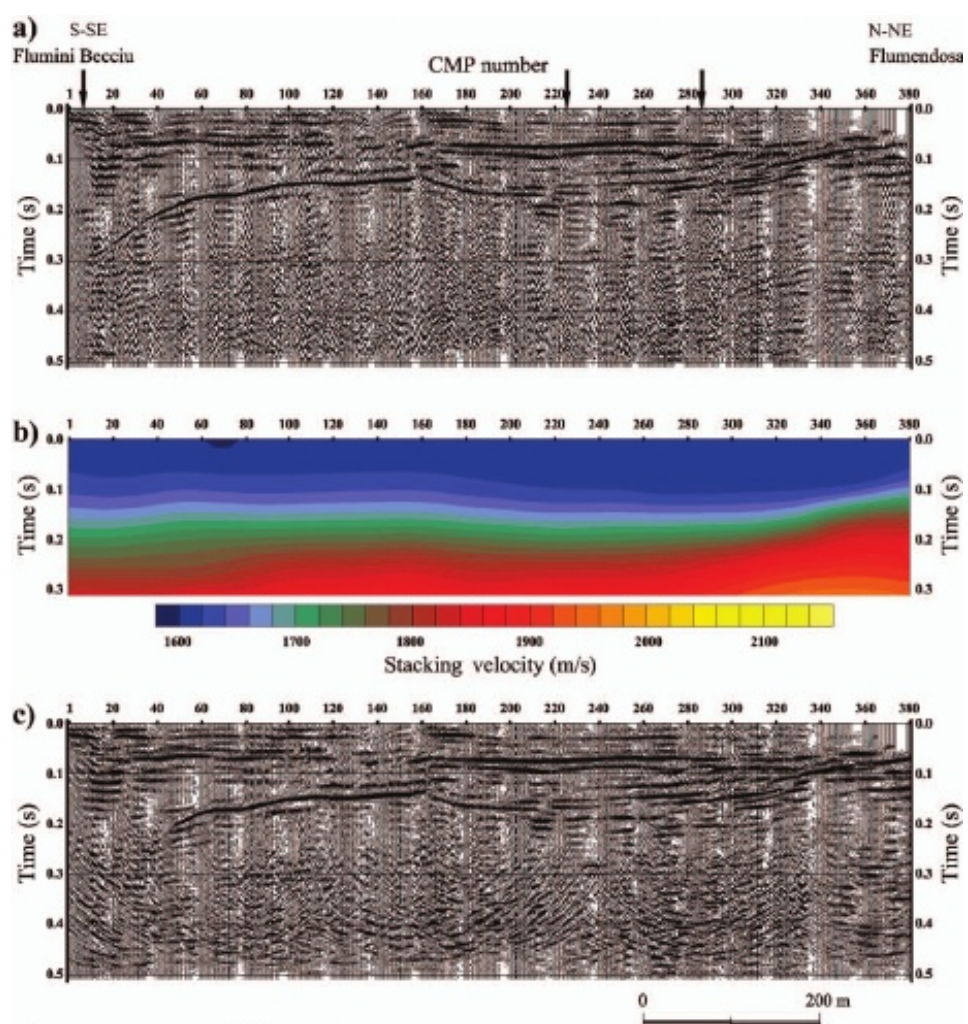

Figure6. (a) Time sectionalong line2 (shown inFigu re1).Arrow s mark shot positions of raw field files in Figure 3. (b) Optimum stacking velocities after dip moveout.(c) An $f-k$ migrated time sectionobtain ed from thetime sectionin Figure6a using an interval-velocityfield derived from stackingveloci tiesin Figure $6 b$.

terraced alluvium. Event $\gamma$, together with events $\alpha$ in the left portion of the section and $\beta$ on the right, delimits seismic unit B. Current informationsugges ts this unitis comprised of continental deposits alone, described as ancient(Pleistocene) alluvial deposits.

However, internal reflection patterns (Figure 10) suggesta different interpretation thatnot only could stimulate geologis ts to revise the geologic history of the area but also could be useful to better define the groundwater-flow dynamics and to evaluate the quality of groundwater (e.g., brackishwater or saltwater).

Between CDPs 150 and 300, in the time windowranging200-26 $0 \mathrm{~ms}$ twtt, oblique progradational facies,charac teristicof fluvial deltas and of associated coastal-plain sediments(Sangree and Widmier, 1979), can be observed. These wellmapped, consistent clinoforms probably represent periodicmeltin gs anddeposi tions in a deltaic environment. In other words, during the Pleistocene, a marine sedimen tation phase locally replaced the largelycontin ental erosion anddeposi tion processes during an interglacial Riss-Würm transgression (Tyrrhenian II). With interaction of fluvial and marine processes, the Tyrrhenian coastline retreated farther inland for some kilometers, creating a deltaic system in the centra part of the plain. The marine conglomerates discovered in the nearby San Priamo plain, $5 \mathrm{~km}$ south of the Muravera plain (Barca et al., 1981), testifyto a similarsituat ion.

Extending event $\gamma$ to the surface, seismic unit A is the only unit along the line that was sampled directly by drilling. Unit A consists of Holocene alluvial deposits comprised of conglomerates, sands, and clays. Events appearing in some parts of thesectionabove reflection $\gamma$ have not been interpreted as genuine reflections. In fact, because the upper $60 \mathrm{~ms}$ of the recorded data are generally contaminated by various types of source-generated, high-amplitude noise

a)
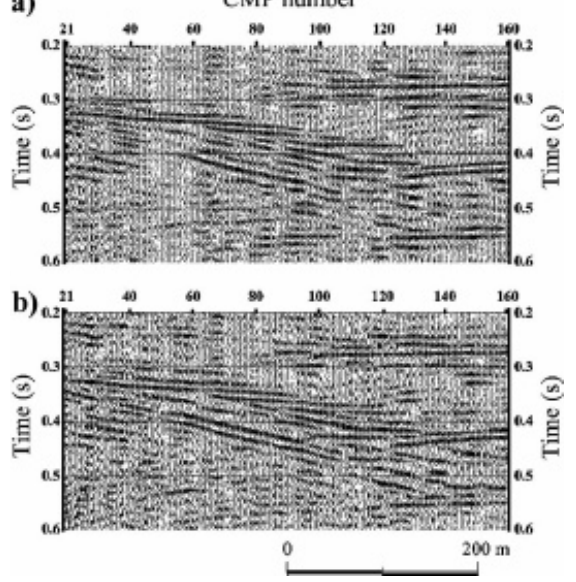

Figure 7. Aportionof timesectio $\mathrm{n} 1$ showing stack improvement(a)
before and (b) after DMO processing. direct, refracted, surface waves, it is not always possibleto discern reflectionsand consistentlysepara te coherent noise andsignal .

\section{Reffection line 2}

Line 2 (seeFig ure 1) begins onthe left bank ofthe FluminiBecc iu channel (500 $\mathrm{m}$ from the end of line 1 ), partially parallels a loop of the Flumendosa River, and terminates on the right bank of the Flumendosa River, $140 \mathrm{~m}$ from the Paleozoic outcrop. Two reflections dominate the section in Figure 9. Event $\alpha$ has apparent dip to the north-northeast from about 290-165 ms twtt between CMP locations 10 and 60 . Then it gently shallows with a dip angle of about $10^{\circ}$, reaching $125 \mathrm{~ms}$ twtt at CMP 160 . In the migrated section the most inclined part of this reflector disappears, suggesting a diffraction (probably a fault) or an artifact of the migration operatorcaused by low coveragein this part of the section.Fro m CMP 160 to the end of the line, event $\alpha$ is less continuous and has lower amplitudes but still can be traced acrossthe section. Thechangein reflection charac-
terof event $\alpha$ could be caused by a change in reflectivityof theover- 
a) $\mathrm{s}-\mathrm{sw}$
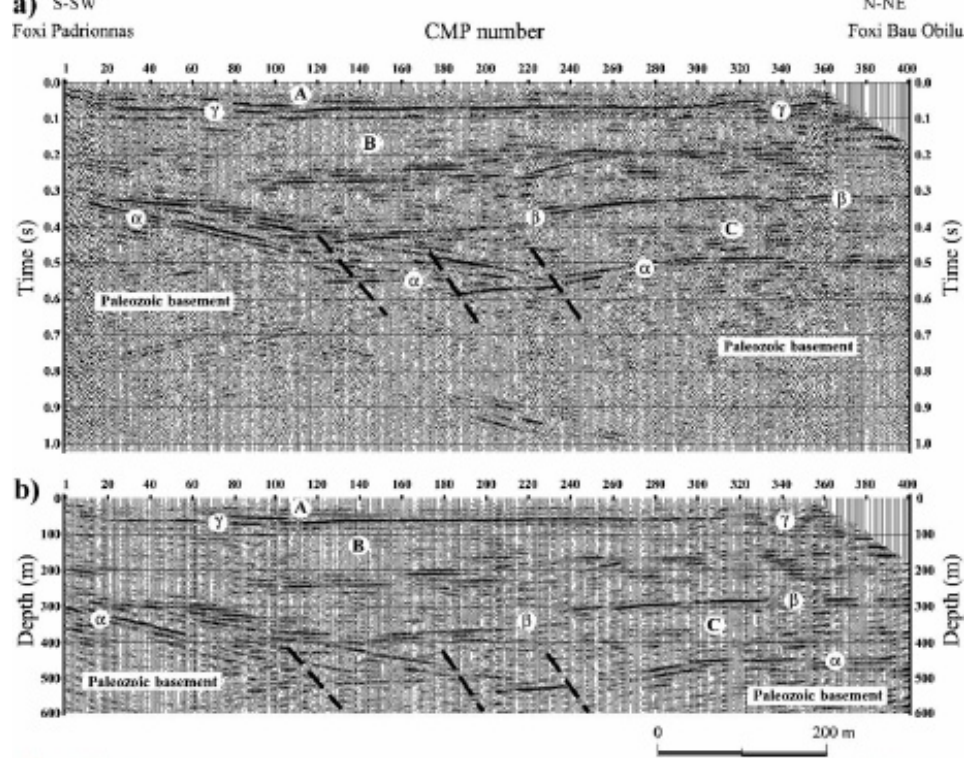

Figure 8. (a) Interpreted time section 1; (b) interpreted depth section 1. Time-to-depth conversion wasmade using interval velocities obtainedusing the Dixequatio $n$ a) $\mathrm{s}-\mathrm{sw}$

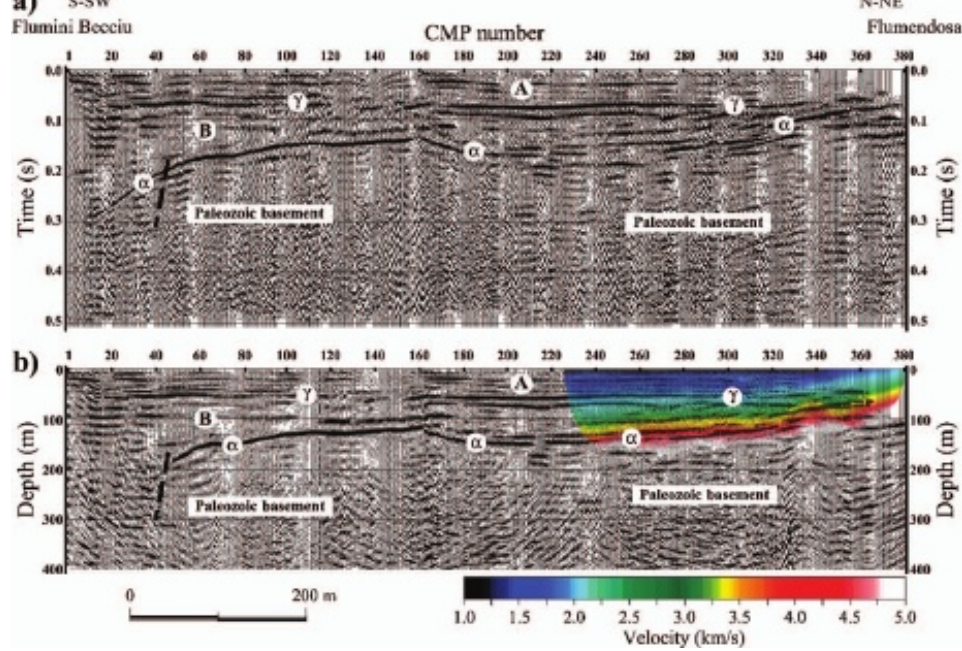

Figure9. (a) Interpretedtime section2; (b) interpreted depth section 2 withveloci ty model superimposed. Time-to-depth conversion was made using interval velocities obtained using the Dix equation. The velocity model was obtained by combining reflection-derived interval velocities and tomographic velocities derivedfrom the direct and refracted arrivals. Velocities increase from $1000-3000 \mathrm{~m} / \mathrm{s}$ in the Quaternary sediments to $3500-4500 \mathrm{~m} / \mathrm{s}$ in bedrock. Event $\alpha$ is representedby a velocitygradie nt rather thanby a discrete interface in the model becausetomogr aphyprodu ces smooth models.

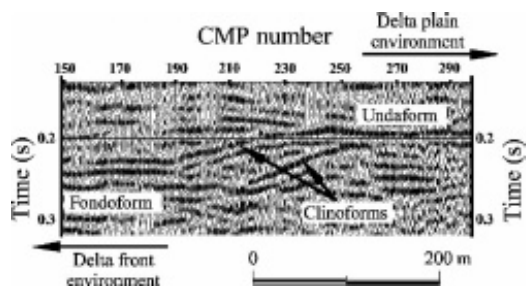

Figure 10. Zoom of time section in Figure 5a showing oblique progradational seismic facies with well-mapped clinoforms characteristic of fluvial delta environments. Undaform zone corresponds to the delta-plain environ-

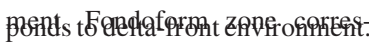

lying sedimentary sequence. After an abrupt deepening between CMPs 160 and 200, event $\alpha$ gently updips from $160 \mathrm{~ms}(\sim 135 \mathrm{~m})$ to $130 \mathrm{~ms}$ twtt $(\sim 105 \mathrm{~m})$ at CMP 300 . From there, it seems to shallow to the end of the line near the Flumendosa River,reaching $66 \mathrm{~ms} \operatorname{twtt}(\sim 52 \mathrm{~m})$.

We interpret event $\alpha$, which is the deepest coherent reflection in the section, as the top of the Paleozoic bedrock. This interpretation is in good agreement withthe outcrop geology and topography.At the end ofthe section, event $\alpha$ isat a depth of approximately $52 \mathrm{~m}$. By extrapolating it up to the Paleozoic bedrock at the surface, which outcrops $260 \mathrm{~m}$ beyond the end of the section, we can tie the subsurface interpretation to the outcrop geology.

The interpretation of event $\alpha$ as the top of the bedrock is also supported by the velocity model obtained by combining reflection-derived interval velocities and those derived from first-arrival information using refraction tomography(Figure $9 b)$. In this velocity model, avail able only at locations where refracted first breaks are clear,reflector $\alpha$ appears to have velocities from 3500 $-4500 \mathrm{~m} / \mathrm{s}$, which are higher than those obtained from reflectionsabove event $\alpha$.

Reflection event $\gamma$ is nearly flat, with onset at $50-70 \mathrm{~ms}$ twtt. It extends from the beginning of the line to CMP location 340, where event $\alpha$ pinches out. Event $\gamma$ probably represents the boundary between Holocene and Pleistocene alluvia. Events above reflection $\gamma$ were not considered for thesam e reasonsas for line 1.

\section{CONCLUSIONS}

The 2D seismic reflection survey carried out in the Muravera plain successfully imaged the subsurface geologic structures of the Flumendosa River Delta. A first-orde $r$ result of the investigation is the clear image of the Paleozoic basement topography. The $>300-\mathrm{m}$ maximum depth to the basement beneath profile 1 was somewhat surprising. The deepest part of the basement, at $580 \mathrm{~ms}$ twtt $(\sim 530 \mathrm{~m})$, isnear ly twiceas deep as expected. Imaging of oblique, progradational seismic facies is another major finding of the investigation. The presence of this seismic pattern, usually characteristic of delta environments, proves that in the Muravera plain, Pleistocene alluvial deposits are partially of marine environment, as are the analogous deposits in the nearby San Priamo plain. This finding is of great importance in better understanding the groundwaterflow dynamics and in guiding other geophysic al investigations aimed at improving the knowledge of groundwater quality (saline content) in the

areànfortunately, because lithologic controls are 
not available, information about the true depth of reflectors and detailed stratigraphic interpretation are unreliable — a problem solvable only through deep-borehole investigations. Despite the inevitableuncertainties on reflector depth andon seismic-unitlithology, the seismic data alone provide a new subsurface model that requires reinterpretation of the geologichistoryof the area.

The well-defined images we producedprove that thestud $y$ area is highly conducive to seismic reflection profiling. This will enable more extensive seismic imaging to be conducted throughout the plain, to gather informationfor constructinga good preliminary subsurface model for other geophysical and hydrogeological investigations. Subsequently, orientedcoringwill allow us to obtain a detailed geologic interpretation that could be of great help to land and resource managers.

Theseismicsection s (1) provideconclusiveevidence of previously undefinedbasement topography and (2) image the verticaland lateral extents of the main formations, which could not be obtained through sparsely spaced drillholes. Furthermore, the study demonstrates thatthe reflection technique can be implementedsuccessfully to provide crucial information for subsurface mapping of structures andstratigraphy in the Muraveraplain.

\section{ACKNOWLEDGMENTS}

We thank F. Di Gregorio for providing informationon thegeology of theMura vera plainand M.A. Melisfor help in manuscript preparation. We also thankL. Noli, M.Sitzia,M. Serci,A.Lai, and G.Casti for their superlative fieldwork. Timely and helpful reviews by an anonymous associate editor and two anonymous journal reviewers are appreciated. This project $\left(\mathrm{n}^{\circ} 25 / 98\right)$ was partially developed undera grant fromthe RegioneAutonoma della Sardegna (L. R. 9/8/50, $\left.n^{\circ} 43\right)$. The support of the University of Cagliari also is acknowledged.

\section{REFERENCES}

Barca, S.,F. Di Gregorio, and V. Palmerini, 1981, Linea di costa Pleistocenica nella pianadi S. Priamo(Sarrabus, Sardegna Sud-orientale): Bollettino dellaSocietàGeologi ca Italiana, 100, 71-84.
Barca, S., and M. Maxia, 1982, Assetto stratigrafico e tettonico del Paleozoicodel Sarrabus occidentale. in Guida allaGeologiadel PaleozoicoSardo: Società Geologica Italiana,87-93.

Birkelo,B. A.. D. W. Steeples, R. D. Miller, andM. Sophocleous, 1987. Seismic reflection study of a shallow aquifer during a pumping test: Ground Water, 25, 703-709

Calvino,F 1961, Lineamentistrutturali del Sarrabus-Gerrei (Sardegna sudorientale): Bollettino del Servizio Geologico d'Italia, 81, 489-556.

Carmignani.L..P. Conti.P. C. Pertusati. S. Barca. N. Cerbai. A. Eltrudis. A. Funedda. G. Oggiano. and E. D. Patta. 2001. Note illustrative della Carta Geologica d'Italia alla scala 1:50000. folio 549 - Muravera: Servizio Geologicod'Italia.

Dix.C. H.. 1955. Seismic velocities from surface measurements: Geophys-

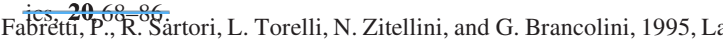
struttura profonda del Margine orientale della Sardegna dall' interpretazione di sismica a riflessione ed a rifrazione: Studi Geologici Camerti, Volume Speciale 1995/2, Convegno Scientifico Nazionale CNR Geodinamica e tettonicaattivadel sistema Tirreno-Appennino, 239-246.

Fitterman.D. V... and M. T. Stewart. 1986. Transient electromagnetic soundingfor groundwater:Geophysics. 51.995-1005.

Geissler. P. E.. 1989. Seismic profiling for groundwater studies in Victoria, Australia:Geophysics, 54.31-37

Goldman, M.,D. Gillar, A. Ronel, andA. Melloul, 1991,Mapp ingof seawater intrusion into the coastal aquifer of Israel by the time domain electromagnetic method: Geoexploration, 28, 152-175.

Jongerius, P., andK. Helbig.1988. Onshore high-resolutionseismic profiling applied to sedimentology: Geophysics, 53,1276-1283.

Liberty, L., 1998, Seismic reflection imaging of a geothermal aquifer in an urban setting: Geophysics, 63, 1285-1294.

Miller, R. D.. and D. W. Steeples. 1990. A shallow seismic reflection survey in basalts of theSnake River Plain. Idaho: Geophysics. 55.761-768.

Miller,R. D.,D. W. Steeples, and M.Brann an,1989, Mappinga bedrock surfaceunder dryalluvium withshallow seismic reflections: Geophysics, 27, 1528-1534.

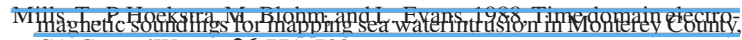
CA:GroundWater, 26,771-782.

Poulsen, L. H., and N. B. Christensen, 1999, Hydrogeophysical mapping with the transient electromagnetic sounding method: European Journal of Environmentaland EngineeringGeophysics, 3,201-220.

Sangree, J. B., and J. M. Widmier, 1979, Interpretationof depositional facies fromseismicdata: Geophysics, 44,131-160.

Shtivelman. V.. and M. Goldman. 2000. Integration of shallow reflection seismics and timedomainelectroma of Israel: Journal of Applied Geophysics, 44,197-215.

Steeples.D. W..A. G. Green.T. V. McEvilly.R. D. Miller. W. E. Doll. andJ. W. Rector, 1997, A workshop examination of shallow seismic reflection surveying: The Leading Edge, 16, 1641-1647.

Whiteley, R. J. J. A. Hunter, S. E. Pullan, and P. Nutalaya, 1998, "Optimum offset" seismic reflection mapping of shallow aquifers near Bangkok, Thailand: Geophysics, 63.1385-1394 